\title{
A NATUREZA JURÍDICA DOS CONDOMÍNIOS EDILÍCIOS E A POSSIBILIDADE DE ELES RECEBEREM DOAÇÕES
}

\section{THE LEGAL NATURE OF BUILDING CONDOMINIUMS AND THEIR POSSIBILITY OF RECEIVEIVING DONATIONS}

\author{
Galdino Luiz Ramos Júnior \\ Mestre em Direito pela Universidade de Marília (SP), \\ Professor da Universidade de Marília (UNIMAR) e Advogado \\ Jefferson Aparecido Dias \\ Doutor em Direitos Humanos e Desenvolvimento pela Universidad Pablo de Olavide (Sevilha), \\ Professor do Doutorado em Direito da Universidade de Marília (UNIMAR) \\ e Procurador da República em Marília (SP)
}

Submissão em 05/07/2017
Aceitação em 07/07/2017

DOI: http://dx.doi.org/10.21671/rdufms.v3i1.4101

\begin{abstract}
Resumo: 0 presente trabalho pretende analisar se os condomínios edilícios, a despeito de possuírem realidade fática, também possuem personalidade jurídica e, nessa qualidade, são titulares de direito de propriedade, sendo possível que recebam, a título de doação, as áreas de uso comum dos condôminos. 0 tema é de grande importância, pois os condomínios edilícios se tornaram uma realidade fática, em especial diante da necessidade do aumento da oferta de imóveis urbanos, causada, dentre outros motivos, pelo êxodo rural que resultou em concentração demográfica nos grandes centros. Além disso, há muito, os condomínios edilícios têm ganhado novos objetivos, ao lado da destinação residencial, sendo cada vez mais destinados para fins empresariais, tecnológicos, de ócio, de lazer e, inclusive, com o fim de atender os interesses de grupos específicos, como é o caso dos condomínios edilícios destinados à residência de pessoas idosas. 0 método adotado será o dedutivo, pois a partir do estudo de preceitos e princípios de caráter geral, se construirá a solução aplicável ao tema aqui proposto. Além disso, a pesquisa terá caráter bibliográfico e documental, direcionada à análise dos textos doutrinários e jurisprudenciais relacionados ao tema.
\end{abstract}

Palavras-chave: Direito de propriedade; Condomínio edilício; Personalidade jurídica; Doação. 
Abstract: The aim of this paper is to analyze if condominiums, in spite of having a factual reality, also have legal personality and, as such, they are owners of property rights, being possible that they receive, as a donation, common use areas of condominium owners. The theme is of great importance, as condominiums have become a factual reality, especially in view of the need to increase the supply of urban properties, caused, among other reasons, by the rural exodus that resulted in population concentration in large centers. In addition, condominiums have long been gaining new goals, alongside the residential destination, being increasingly intended for business, technological, leisure, and even for the purpose of meeting the interests of specific groups, as is the case of condominiums for the residence of elderly people. The method adopted is the deductive one, since from the study of precepts and principles of general character, the solution applicable to the theme proposed here will be constructed. In addition, the research has a bibliographic and documentary character, directed to the analysis of the doctrinal and jurisprudential texts related to the subject.

Keywords: Property right. Building condominium. Legal personality. Donation.

SUMÁRIO: 1. Introdução. 2. Do condomínio edilício: considerações gerais. 3. A instituição do condomínio edilício e sua natureza jurídica. 4. Do condomínio edilício como beneficiário de doação. Conclusão. Referências.

\section{INTRODUÇÃO}

Se é certo que o direito é um fenômeno social, também é correto afirmar que a evolução da sociedade impõe uma transformação do direito, a fim de que ele seja apto a ser aplicado a novas realidades, em um novo contexto. Neste sentido, o condomínio edilício, a despeito de ter sua origem no Direito Romano, tem adquirido novo formato com a alteração da realidade social.

Diante dessa nova realidade, o objetivo do presente artigo é analisar se os condomínios edilícios, além de possuírem realidade fática, também possuem personalidade jurídica e, nessa qualidade, podem ser titulares do direito fundamental à propriedade e, inclusive, receber em doação as áreas comuns do condomínio.

No passado, o condomínio edilício representava, em regra, a mera divisão do direito de propriedade entre mais de um titular, admitindo que mais de uma pessoa exercesse seu direito sobre um mesmo bem. Atualmente, contudo, com o desenvolvimento de grandes centros urbanos, sedimentando um processo irreversível de êxodo rural e de concentração demográfica, demandam o surgimento de novas formas de habitação e construção, destinadas a cumprir fins específicos.

Obter o máximo de utilização de uma área territorial, gerando múltiplos espaços de habitação, lazer, indústria e de comércio, é o objetivo que inspira a criação de inúmeros empreendimentos imobiliários. Dentre tais empreendimentos temos os novos condomínios edilícios apresentados, neste trabalho, tanto na 
modalidade vertical, quanto na horizontal, com fins que vão desde o lazer até a moradia de pessoas idosas.

Apesar de existência de diplomas normativos responsáveis pela regulação do instituto - em especial a Lei no 4.591/64, alterada pela Lei no 4.864/65, além do vigente Código Civil de 2002 - é fato que a legislação não esgota todas as nuances que envolvem a figura em questão.

0 entendimento dominante, quando se fala de condomínio edilício, é da ausência de sua personalidade jurídica, não podendo atuar de "per si”, razão pela qual se observam incongruências no pensamento científico atual sobre o tema, notadamente quando confrontado com aspectos fáticos e legais que acabam por, ainda que sem preocupação jurídica, conceder direitos e deveres efetivos aos condomínios, contrariando o pensamento de ausência de sua personalidade jurídica.

Exemplifica-se com a possibilidade de tais entidades figurarem em juízo, ativa e passivamente, cobrando verbas condominiais ou sofrendo ações e, até mesmo, execuções fiscais.

O condomínio edilício ficaria então em um "limbo normativo", pois não teria personalidade jurídica, mas poderia praticar atos inerentes a quem possuísse personalidade jurídica. Diante desta antítese, cada vez mais o Poder Judiciário é chamado a intervir em diversos aspectos que envolvem o tema, dentre os quais se optou pela análise da doação realizada ao condomínio edilício pela empreendedora negocial de área imóvel de interesse do todo condominial.

O método adotado será o dedutivo pois, a partir do estudo de preceitos e princípios de caráter geral, se construirá a solução aplicável ao tema aqui proposto. Além disso, a pesquisa terá caráter bibliográfico e documental, direcionada à análise dos textos doutrinários e jurisprudenciais relacionados ao tema, com o fim de fornecer resposta à hipótese suscitada, sem a pretensão de esgotamento da temática, mas sim de instigar o leitor a se aprofundar no assunto, ainda carente de maiores estudos específicos.

\section{DO CONDOMÍNIO EDILÍCIO: CONSIDERAÇÕES GERAIS}

A origem do denominado "condomínio" remonta à antiguidade, sendo encontrados traços característicos da figura no Direito Romano, como aponta Caio Mario da Silva Pereira (2004, p. 184):

Uma pesquisa histórica permite recuar a superposição habitacional ao Direito Romano, onde já se conhecia a prática da insula destinada à resi- 
dência plebeia, como dá notícia Tácito ao descrever o incêndio de Roma ao tempo de Nero.

Outros autores reconhecem indicativos da existência do condomínio entre os sumérios (VENOSA, 2013, p. 288) ou na Babilônia, dois mil anos antes de Cristo (RIZZARDO, 2017).

Contudo, apesar de essas divergências em relação à sua origem histórica, o certo é que o condomínio se confunde com a própria história do direito de propriedade (TORRADO, 2015), uma vez que era concebido como o exercício de tal direito em conjunto por mais de uma pessoa. Nesse sentido, bastante elucidativa a origem da expressão que é trazida por Arnaldo Rizzardo (2017), o qual esclarece que "o termo cum significa conjuntamente, enquanto a palavra dominum expressa domínio, propriedade. Portanto, condomínio é propriedade conjunta - que pertence a mais de um".

O Código Civil de 1916, em seus arts. 623 a 646, estabelecia regras para o condomínio, prevendo os direitos e os deveres dos coproprietários. Importante esclarecer, contudo, que em seus primórdios e até mesmo no Código Civil de 1916, o condomínio pressupunha a propriedade conjunta de todo um imóvel ou bem e não reconhecia a existência de áreas sujeitas à propriedade privativa e outras sujeitas à propriedade comum.

Porém, a formação de grandes concentrações urbanas, a escassez de espaços territoriais nas suas áreas centrais e a necessidade de oferecimento de habitação para um grande contingente populacional, fruto, dentre outros fatores, do forte êxodo rural verificado, trouxeram a necessidade de regulamentar a figura do denominado "Condomínio Edilício", o que se deu em primeiro momento com a edição do Decreto no 5.481/28, alterado, primeiro pelo Decreto Lei no 5.234/43 e, depois, pela Lei no $285 / 48$.

0 incremento no número das edificações horizontais, bem como a ampliação dos empreendimentos imobiliários na modalidade de incorporações, demandaram uma especialização normativa maior, o que se deu com a edição da Lei no 4.591, de 16/12/1964 posteriormente alterada parcialmente pela Lei $\mathrm{n}^{\mathrm{o}}$ 4.864, de 29/11/1965. A Lei no 4.591/64, possui duas partes bastante destacadas, sendo a primeira dedicada aos condomínios em edificações e, a segunda, às incorporações imobiliárias, trazendo elementos de direito obrigacional, ou seja, do liame jurídico-contratual havido entre incorporador/empreendedor e o adquirente do bem.

Com a publicação dessa legislação especial surgiu, no Brasil, a figura do condomínio edilício, que se diferencia do condomínio comum pelo fato de existir, 
no mesmo bem, partes sujeitas à propriedade privada de uma ou mais pessoas e outras partes que se destinam ao uso comum de todos e, portanto, são da propriedade de todos os titulares das partes sujeitas à propriedade privada. Na lição de Arnaldo Rizzardo (2017), “condomínio edilício é a copropriedade numa edificação da qual constam unidades privativas autônomas, de uso exclusivo, e partes que são propriedade comum dos condôminos".

O Código Civil de 2002, ao contrário do Código Civil de 1916, que tratava apenas do condomínio, tratou expressamente do condomínio edilício, em seus arts. 1.331 a 1358, modernizando significativamente a legislação brasileira referente ao mencionado instituto e procurando adaptá-lo à realidade fático-social contemporânea. Com a entrada em vigor de tais preceitos, há quem defenda a derrogação (revogação parcial) da Lei no 4.591/65, no que concerne à sua porção definidora do condomínio edilício, mantendo-se, no entanto, as normas atinentes às incorporações imobiliárias.

Essa é a posição de Flavio Tartuce (2012, p. 933/934) que, para justificar seu entendimento, faz um breve relato da adequação do instituto à nova codificação civil:

O CC/2002 passou a disciplinar o condomínio edilício, o que é tido como feliz inovação, eis que o fenômeno real muito interessa à contemporaneidade, merecendo um tratamento específico na codificação privada. Conforme relatam Jones Figueiredo Alves e Mario Luiz Delgado, doutrinadores que participaram no processo de elaboração da atual lei civil, o termo condomínio edilício foi introduzido por Miguel Reale, por se tratar de expressão nova de incontestável origem latina, muito utilizada, por exemplo, pelos italianos. Ainda são usados os termos condomínio em edificações e condomínio horizontal (eis que as unidades estão horizontalmente uma para as outras)

O CC/2002 consolidou o tratamento que constava da primeira parte da Lei 4.591/1964 (arts. 1ํo a 27). Sendo assim, filia-se à corrente que sustenta a revogação tácita de tais comandos, nos termos do artigo $2^{\circ}$, parágrafo $1^{\mathfrak{o}}$, da Lei de Introdução, eis que a codificação regulou inteiramente a matéria.

Por essa posição, atualmente os condomínios edilícios estariam totalmente regulamentados pelo Código Civil de 2002, restando revogada, nesta parte, a Lei no 4.591/65, a qual estaria vigente apenas na parte que trata das incorporações. Essa regulamentação trazida pelo Código Civil de 2002 atingiria tanto o exercício da propriedade privada da parte de uso exclusivo, quanto a propriedade conjunta das áreas em comum, principal característica dos condomínios edilícios. 
Sobre o tema, Caio Mario da Silva Pereira (2012, p.185), ainda leciona que:

A essência do condomínio nos edifícios coletivos reside em que deve ele ser constituído de partes que são de utilização exclusiva, consistindo no direito de propriedade sobre a unidade do seu titular, e partes que são comuns a todos, devendo o direito sobre as mesmas ser subordinado ao conceito condominial, tal como desenvolvido em o no 314 , supra. 0 proprietário de uma unidade no edifício coletivo somente tem a possibilidade material e jurídica de sua utilização se ao mesmo tempo lhe é assegurada a das partes comuns. Daí resulta que o conceito de condomínio edilício há de assentar na reunião orgânica e indissolúvel da propriedade exclusiva, incidente sobre a unidade, e o condomínio sobre as partes e coisas comuns.

Portanto, em matéria de condomínio edilício o proprietário é titular de um direito que se apresenta em nuances próprias, levando-se em consideração suas porções individuais e subjetivas e, outrossim, porções coletivas/sociais exercidas em atenção aos demais coproprietários.

\section{A INSTITUIÇÃO DO CONDOMÍNIO EDILÍCIO E SUA NATUREZA JURÍDICA}

O condomínio edilício, com suas características peculiares, tem seu formato de instituição previsto no art. 1.332, do Código Civil de 2002, o qual prevê que ele pode ser criado "por ato entre vivos ou testamento, registrado no Cartório de Registro de Imóveis", sendo imprescindível que do seu ato de criação conste expressamente:

Art. 1.332

(...)

I - a discriminação e individualização das unidades de propriedade exclusiva, estremadas uma das outras e das partes comuns;

II - a determinação da fração ideal atribuída a cada unidade, relativamente ao terreno e partes comuns;

III - o fim a que as unidades se destinam.

O registro da constituição condominial com as discriminações acima elencadas é formalidade solene indispensável para a validade do ato, sendo, inclusive, garantia fundamental dos futuros adquirentes e coproprietários.

Em complemento a tal preceito do Código de Processo Civil, a Lei de Registros Públicos (Lei $\mathrm{n}$ 6.015/73) estabelece as formalidades para o ato registral do condomínio em seu art. 237-A, $\S 1^{\circ}$, $2^{\circ}$ e e $3^{\circ}$. Dentre as exigências estabelecidas na referida lei especial, salienta-se a que determina a especificação clara e precisa 
das finalidades do empreendimento, o que é plenamente justificável, uma vez que a definição precisa do fim a que se destina o empreendimento condominial, de forma bem delimitada, evitará desvios de utilização pelo proprietário, bem como eventuais conflitos que exijam a atuação do Poder Judiciário.

Modernamente tem-se observado a instituição de condomínios edilícios com fins residenciais ou com destinações comerciais específicas, como escritórios, clínicas e, até os denominados "adult homes", ou seja, "edifícios planejados e destinados a aposentados em provecta idade, com regulamento a eles destinados" (VENOSA, 2013, p. 294). Também começaram a surgir condomínios-clubes, os quais concentram áreas residenciais com espaços dedicados ao lazer (ARAÚJO, 2015).

Contudo, apesar do Código Civil e da Lei de Registros Públicos trazerem os preceitos que regulamentam a criação dos condomínios edilícios, resta em aberto a questão relacionada à sua natureza jurídica, pois inexiste preceito legal que lhe atribua personalidade jurídica, a qual lhe garantiria a possibilidade de aquisição de direitos na ordem civil.

Atualmente, o rol de pessoas jurídicas de direito privado consta dos incisos do art. 44, do Código Civil, e não contempla os condomínios edilícios, restando, assim, a discussão quanto à natureza de tal rol, ou seja, se ele é "numerus clausus" ou "numerus apertus".

Assim, se o rol do art. 44 do Código Civil for considerado um rol exaustivo, não é possível a sua ampliação, razão pela qual não seria possível, ainda que em tese, atribuir ao condomínio edilício a personalidade jurídica, razão pela qual ele não teria condições, por obviedade, de ser beneficiário de atos de obtenção patrimonial.

Por outro lado, caso o mencionado rol seja considerado exemplificativo, seria possível a sua ampliação, por meio de uma interpretação extensiva, a qual permitiria atribuir personalidade jurídica ao condomínio edilício, reconhecendo a possibilidade de praticar certos atos negociais da vida civil, dentre os quais, o recebimento de patrimônio por doação, objeto específico de estudo do presente artigo. A doutrina não tem enfrentado a questão com aprofundamento que seria desejável.

Para parte da doutrina, os condomínios edilícios não possuem personalidade jurídica, a qual seria exclusiva dos proprietários das unidades autônomas que, nessa qualidade, também seriam os proprietários das partes comuns. Defendendo essa posição, Caio Mario da Silva Pereira (2004, p. 187) apregoa que:

Os titulares dos direitos, quer sobre as unidades autônomas, quer sobre as partes e coisa comuns, são os condôminos e não uma inexistente ou 
fictícia pessoa jurídica. 0 condomínio dito edilício explica-se por si mesmo. É uma modalidade nova de condomínio, resultante da conjugação orgânica e indissolúvel da propriedade exclusiva e da co-propriedade.

Não obstante tal entendimento, negar personalidade jurídica ao condomínio edilício acaba por restringir indevidamente as suas atividades, em postura que, para alguns autores, acaba por desprestigiar princípios constitucionais da ordem econômica, conforme previsto no art. 170, da Constituição Federal, em especial a livre iniciativa, a propriedade privada, a função social da propriedade e o livre exercício da atividade econômica.

Neste sentido, a figura do condomínio edilício deve transcender à mera existência normativa, para, em uma visão dinâmica dos fenômenos sociais, ser considerada, em sua inteireza, verdadeira pessoa jurídica, com a capacidade de atuar como sujeito de direitos e deveres na ordem jurídica, participando, ativamente, da fenomenologia negocial, criando a relação jurídica privada propriamente dita. 0 reconhecimento da personalidade jurídica ao condomínio, já sufragada por vários autores, exsurge com força e dinamismo em concepções contemporâneas de direito privado. Defensor dessa posição, Silvio Venosa (2013, p. 290-291) sustenta a necessidade de caracterização do condomínio edilício como detentor de uma “personificação anômala”, explicando:

No entanto, no mundo negocial, o condomínio age tal qual uma pessoa jurídica. Em nossa obra Direito Civil: parte geral (seção 13.6.2), aduzimos que o direito não pode ignorar realidades. 0 condomínio de edifícios possui o que denominamos personificação anômala. Qualificamo-lo como entidade com personificação anômala.

$[\ldots]$

O condomínio atua na vida negocial como qualquer pessoa jurídica, dentro de seu âmbito de atuação. A realidade não admite outra solução. 0 condomínio tem, portanto, existência formal (STJ - 4aㅡ. T., RE 9.584-SP, Rel. Min. Sálvio Figueiredo, In: Theotônio Negrão, Código de Processo Civil e legislação processual em vigor, nota 23 ao art. 12). Sua personificação mitigada é inafastável. Sua personalidade jurídica é reconhecida expressamente, por exemplo, na legislação francesa, cuja doutrina o qualifica como uma criação original do legislador.

Assim, a modernidade negocial e a inserção da figura do condomínio edilício em seu contexto, lhe dá o formato fático de pessoa jurídica, razão pela qual, a fim de evitar uma grave lacuna normativa, cabe à doutrina e ao Poder Judiciário seu reconhecimento como uma realidade jurídica.

Flavio Tartuce (2012, p. 940), citando Frederico Henrique Viegas de Lima, reconhece que "a personificação jurídica da comunidade de coproprietários em 
condomínios especiais em edificações é decorrente das necessidades econômicas e sociais da atualidade". Na realidade, a aplicabilidade de tal posição, que defende a personalidade jurídica aos condomínios edilícios é passível de ser observada em várias circunstâncias da dinâmica jurídica, normativa e negocial vigente no Brasil.

Neste sentido, pode ser citado o reconhecimento da legitimidade processual ativa e passiva do condomínio estar em juízo, representado por seu síndico (art. 75, inciso XI, do Código de Processo Civil), bem como pela possibilidade do condomínio adquirir as unidades dos condôminos insolventes, prevista no art. 63, § 3ㅜㅡ, da Lei no ${ }^{\circ} .591 / 64$.

Tal legitimidade processual "ad causam" reconhecida ao condomínio edilício impele reconhecer sua personificação jurídica, pois, está o ente a atuar em nome próprio, ainda que no interesse de terceiros. Assim, a legitimidade processual repercute sua prerrogativa de figurar em Juízo, exigindo e recebendo direitos inerentes a tal atividade. Além disso, o consectário do exercício de direito de ação ao condomínio edilício se materializa com a efetividade do processo, ou seja, com o recebimento da prestação inadimplida por parte do condômino infrator, inclusive, através da prática de atos executivos diretos sobre o patrimônio do devedor.

Já o preceito constante da legislação condominial, admitindo que o condomínio, após decisão unânime de sua Assembleia Geral, adjudique o bem do condômino levado a leilão, também deixa claro que lhe deve ser reconhecida a personalidade jurídica, pois, afinal, ao se reconhecer um dever de adimplemento do condômino em face do condomínio, decorrente de uma violação a uma relação obrigacional entre ambos, também se reconhece o condomínio edilício como uma personalidade jurídica titular de direitos.

A par desses preceitos legais, outro aspecto interessante e esclarecedor, que impõe o reconhecimento de personalidade jurídica do condomínio edilício, é a possibilidade, já reconhecida pela Jurisprudência, de ele figurar como locador de espaços comuns inerentes ao empreendimento e, no caso de inadimplemento, promover a respectiva a ação de despejo cumulada, ou não, com a respectiva ação de cobrança. Nesse sentido já decidiu o Tribunal de Justiça do Estado de Santa Catarina (SANTA CATARINA, 2009):

CIVIL - DESPEJO C.C. COBRANÇA - CONTRATOS DE LOCAÇÃO E DE CESSÃO DE DIREITO - SHOPPING CENTER - LEGITIMIDADE ATIVA DO RESPECTIVO CONDOMÍNIO - APLICAÇÃO DO CPC, ART. 515, § 3ำ

1. 0 condomínio formado pelos proprietários do imóvel é parte legítima para ajuizar ação de despejo e de cobrança de haveres do locatário. 
Eventual dúvida sobre a representatividade daquele deve ser resolvida a favor da efetividade do processo e da finalidade útil das formas.

2. Tendo o devedor confessado o pagamento parcial dos aluguéis e não comprovado a quitação dos valores estipulados nos Contratos de Cessão de Direito de Uso, indesviável a sua condenação ao pagamento do montante com que se comprometeu contratualmente a honrar ao alugar espaço em shopping center.

JUROS DE MORA E CORREÇÃO MONETÁRIA - INCIDÊNCIA.

1. "A correção monetária, mera atualização do valor da moeda naufragada em tormentosa inflação, constitui justa solução para todas relações jurídicas com o fim de resgatar a real expressão do poder aquisitivo original" (REsp n. 51.814/SP, Min. Milton Luiz Pereira). Por isso, demonstrado o inadimplemento do devedor, impõe-se a atualização monetária. Da mesma forma, são devidos juros moratórios, pois a correção monetária nada mais é do que mera recomposição do valor real da moeda, enquanto aqueles constituem sanção ao devedor pelo retardamento no cumprimento da obrigação.

Ao lado da possibilidade de figurar nos polos ativo e passivo de ações judiciais, bem como o de adjudicar o bem de condômino inadimplente, a possibilidade de o condomínio celebrar contrato de locação e promover ação de despejo no caso de inadimplemento, reforçam a tese de que deve ser reconhecida personalidade jurídica aos condomínios edilícios.

Por fim, em um último esforço argumentativo em defesa do reconhecimento da personalidade jurídica dos condomínios edilícios e sem esgotar o assunto, pode ser trazida a possibilidade de o condomínio ser demandado por tributos oriundos do exercício de suas finalidades. Nesse sentido, a jurisprudência, há tempos, reconhece sua legitimidade passiva que, analisada em um contexto negocial, indica, também, sua personalidade jurídica. 0 Tribunal Regional Federal da 3ª Região (BRASIL, 1998) já adotou tal posição:

1. PROCESSO CIVIL - AGRAVO DE INSTRUMENTO - EXECUÇÃO FISCAL OBRIGAÇÃO TRIBUTÁRIA - CONDOMÍNIO - RESPONSABILIDADE.

2. 1 - Mesmo que o condomínio não esteja registrado, tem ele para efeitos tributários, legitimidade para figurar no polo passivo da execução fiscal.

3. 2 - Agravo de Instrumento provido.

O fato de poder figurar no polo passivo de uma execução fiscal decorre do fato de o condomínio possuir obrigações tributárias, diferentes das obrigações tributárias dos proprietários de suas unidades, razão pela qual deve ser reconhecida a sua personalidade jurídica. 
Diante de todos esses argumentos, Flávio Tartuce conclui, apresentando as vantagens da adoção da tese de personificação do condomínio edilício (2012, p. 940/941):

1ạ. Vantagem - As reuniões de condomínio são profissionalizadas e facilitadas, delas participando apenas condôminos eleitos, com direito a voto, a exemplo do que ocorre com as associações.

$2^{\mathrm{a}}$. Vantagem - Os condôminos edilícios pessoas jurídicas podem prestar serviços diversificados diretamente aos seus condôminos, como atividades de recreação e esportivas, bem como serviços de transporte. Conforme destacou Frederico Viegas em sua palestra, na realidade atual, condomínios das grandes cidades constituem associações para tais fins, o que passa a ser desnecessário com a tese que se propõe.

3a. Vantagem - Os condomínios podem adquirir imóveis por adjudicação. ... A propriedade é concretamente funcionalizada, transformando-se o condomínio em forma de investimento. Ilustrando na prática, o condomínio pode adquirir os imóveis, dos condôminos inadimplentes, locando-os posteriormente a terceiros. Com isso, os condôminos restantes adquirem o domínio da unidade, além de usufruírem da locação que reduz o valor da contribuição mensal.

Em complemento à posição de Flávio Tartuce, também podem ser apresentados os argumentos de Silvio Venosa (2013, p. 290), que também defende a viabilidade de ser reconhecida personalidade jurídica aos condomínios edilícios:

Por essa razão, afiguram-se descabidas, estéreis e empedernidas discussões sobre a personalidade do condomínio regido pela Lei $\mathrm{n}^{\mathrm{o}}$ 4.591/64 e agora pelo novo Código Civil, as quais, no entanto, têm consequências práticas desastrosas para os interessados. Atenta contra a realidade do ordenamento o cartório imobiliário que, por exemplo, se recusa a transcrever unidade autônoma em nome do condomínio. Nada impede que a comunidade condominial decida ser proprietária, por exemplo, de lojas ou estacionamento no edifício, explorando-os comercialmente e com isso reduzindo as despesas condominiais dos titulares das unidades autônomas. Nunca se negou a possibilidade de o condomínio deliberar e decidir locar dependência sua para restaurante ou outra finalidade mercantil.

Como se vê, várias são as vantagens de reconhecimento da personalidade jurídica dos condomínios edilícios, faltando ser analisada, apenas, para conclusão do objetivo proposto no presente artigo, se tais condomínios podem ser beneficiários de doações, tema que será analisado no próximo item. 


\section{DO CONDOMÍNIO EDILÍCIO COMO BENEFICIÁRIO DE DOAÇÃO}

Superada a discussão sobre a possibilidade de ser atribuída personalidade jurídica ao condomínio edilício, questão respondida afirmativamente no item anterior, resta a dúvida sobre a possibilidade de o condomínio edilício ser beneficiário de doações.

O contrato de doação está regulamentado pelos arts. 538 a 564, do Código Civil, sendo conceituado pelo legislador como modalidade de avença onde uma pessoa, por liberalidade, transfere do seu patrimônio bens ou vantagens para o de outra. A doação, negócio jurídico em essência, poderá ser feita por escritura pública ou instrumento particular, apresentando os seguintes caracteres jurídicos (FIUZA, 2012, p. 561):

Quanto a suas características, a doação é contrato:

- típico, pois está regulada nos arts. 538 a 564 do Código Civil;

- puro, porque não é fruto da mistura de dois ou mais outros contratos; - consensual ou formal, dependendo do valor da doação. Se de baixo valor, consensual; se de alto valor, formal. Com base na redação do art. 538, poder-se-ia defender ser o contrato de doação real, considerando-se celebrado somente após a tradição da coisa. Isto porque o referido artigo dispõe que, pelo contrato de doação, o doador transfere ao donatário a propriedade de um bem. Ora, se o contrato fosse consensual, teria o legislador se expressado adequadamente, como na compra e venda (art. 481), dispondo que, pelo contrato de doação, o doador se obriga a transferir ao donatário a propriedade de um bem. Sendo a doação considerada contrato real, antes da tradição, haveria apenas promessa de doação, exigível nos termos que estudaremos mais adiante;

- gratuito ou atributivo, uma vez que não há nenhum ônus suportado pelo donatário que chegue a configurar contraprestação pela vantagem auferida. À prestação do doador não corresponde qualquer contraprestação ao donatário;

- unilateral, pois que somente o doador tem obrigações. Será bilateral se for onerado com encargo, como veremos abaixo;

- pré-estimado, por ser a prestação do doador conhecida desde o momento da celebração. Mas pode também ser aleatório, se seu objeto não for conhecido no momento da celebração. Por exemplo, doação em que o doador se comprometa a entregar sua safra;

- de execução imediata ou futura. Normalmente, executa-se logo após a celebração, mas nada impede que se execute em outro momento, quando será contrato de execução futura;

- individual, pois obriga apenas as partes contratantes;

- negociável, por serem suas cláusulas sempre passíveis de negociações, ainda que só em teoria. 
- intuitu personae, uma vez que celebrado em razão da pessoa do donatário.

Diante das características acima descritas e dos preceitos legais citados, o questionamento que surge é se o condomínio edilício pode receber, em doação, um bem imóvel. Assim, o objeto de estudo do presente trabalho consiste na análise sobre a viabilidade jurídica de um condomínio edilício, em que pese as discussões acerca da existência ou não de sua personalidade jurídica, figurar como donatário em escritura pública de doação patrimonial, sendo tal ato hábil a registro no Serviço Registral competente. A resposta a tal dúvida deve, necessariamente, partir do contexto do ato de doação e o interesse nela presente. Em outras palavras, deve-se investigar a motivação do ato e se ele foi praticado no interesse do condomínio edilício em concreto, ou seja, se inerente às suas atividades e a sua situação fático-jurídica.

A título de exemplo, imagine-se a proposta de doação, voluntária, de uma vaga de garagem remanescente da incorporação do imóvel objeto do condomínio, de propriedade da incorporadora, para o condomínio edilício.

Ora, a utilidade da vaga ao condomínio edilício é evidente, pois poderá facilitar o trânsito e as manobras de veículos, podendo ser utilizada, também, para o estacionamento de veículos de entrega ou de visitantes, e, até mesmo, ser objeto de locação para um dos condôminos, com a utilização do valor arrecadado em benefício de todos os condôminos ou do próprio condomínio.

Além da doação de vagas de garagem, o condomínio também poderá ter interesse no recebimento, em doação, de estacionamento ou lojas no edifício, os quais, conforme lição já citada de Silvio Venosa (2013, p. 290), podem ser explorados comercialmente, visando reduzir as despesas condominiais dos proprietários das unidades autônomas.

Assim, desde que reconhecida a utilidade do bem, o ato do condomínio que o recebe em doação, incorporando-o ao seu patrimônio e, por consequência, ao patrimônio de todos os condôminos, deve ser considerado válido e eficaz, merecendo guarida do Direito, inclusive e notadamente, do Direito Registral.

Aliás, é o que tem entendido o Poder Judiciário nas situações em que é instado a analisar situações específicas sobre o tema, notadamente em arguições de dúvidas registrais, a teor do dispostos nos arts. 198 e seguintes da Lei de Registros Públicos. Nesse sentido, podem ser citados dois posicionamentos tidos como emblemáticos, sendo o primeiro deles do Tribunal de Justiça do Rio Grande do Sul, no julgamento da Apelação Cível nº 70069628204 (RIO GRANDE DO SUL, 2016), no qual se decidiu: 
APELAÇÃO CÍVEL. REGISTRO DE IMÓVEIS. DÚVIDA. AQUISIÇÃO DE PROPRIEDADE ATRAVÉS DE DOAÇÃO POR PARTE DO CONDOMÍNIO. POSSIBILIDADE. SENTENÇA MODIFICADA. Tratando-se de condomínio devidamente registrado no Cadastro Nacional de Pessoa Jurídica (CNPJ), com número próprio e não se tratando somente de sociedade de fato, tem ele personalidade jurídica para adquirir imóveis. DERAM PROVIMENTO AO RECURSO DE APELAÇÃO. UNÂNIME.

A segunda decisão digna de ser citada foi proferida pelo Tribunal de Justiça de Santa Catarina, no julgamento da Apelação Cível no 2013.014872-6 (SANTA CATARINA, 2015):

SUSCITAÇÃO DE DÚVIDA. CONDOMÍNIO. REGISTRO DE DOAÇÃO DE UNIDADE AUTÔNOMA, QUE PASSA A INTEGRAR O PATRIMÔNIO COMUM. VIABILIDADE, CONTANTO QUE OBSERVADAS AS MESMAS FORMALIDADES DO REGISTRO DO CONDOMÍNIO, NOS TERMOS DO ART. 1.332, II, DO CÓDIGO CIVIL.

A preservação do espírito da norma inserta no art. 5 da LINDB pressupõe atenção não apenas ao fim almejado pela norma, mas à realidade em que ela irradia efeitos. 0 intérprete do direito deve acompanhar as transformações na realidade social, evitando-se que a tentativa de enquadrar os fatos em categorias ultrapassadas leve a decisões injustas e incompatíveis com o escopo da norma. 0 condomínio é instituto jurídico que representa a co-propriedade de um determinado bem. É uma situação de fato, antes do que uma entidade. Todavia, o condomínio edilício, além de ser registrado, assume uma série de deveres que são próprios de pessoas jurídicas, de forma que é inexato afirmar-se categoricamente que tenha unicamente capacidade postulatória, mas não personalidade jurídica. Na competência do síndico, estabelecida no inciso II do art. 1.348 do Código Civil, insere-se a de diligenciar administrativamente perante os órgãos públicos para a prática dos atos de interesse do condomínio, respeitados os limites impostos pela legislação e pela convenção dos condôminos. Considerando-se que para o registro do condomínio é necessária a determinação da fração ideal atribuída a cada unidade (CC, art. 1.332, II), então a alteração da área comum deverá igualmente ser levada a registro, com as mesmas especificações.

Nos casos acima citados, a aceitação do condomínio edilício como beneficiário de doação decorre de um raciocínio exegético pleno, que reconhece o condomínio edilício como detentor de personalidade jurídica e o recebimento de um bem em doação como uma das formas de atingir os seus fins.

Afinal, se o condomínio edilício possui capacidade processual, pode adjudicar bens, pode figurar como locador em contratos de locação, responde em 
execução fiscal como responsável tributário, dentre outros direitos e deveres, também pode ser beneficiado com doação de bem que lhe permita cumprir os fins para os quais foi constituído. 0 exame, outrossim, das condições da doação cabe ao intérprete/aplicador do Direito, levando-se em conta os objetivos do ato e o benefício ao condomínio, no que tange às suas finalidades primordiais.

Assim, nada há que impeça um condomínio edilício, regularmente constituído, de receber doação de bem que venha em consonância aos seus interesses legítimos, beneficiando os titulares das unidades autônomas e facilitando a implementação de seus objetivos fixados quando de sua constituição.

Pensar o contrário é distanciar o Direito de seu papel de fenômeno social que acompanha o dinamismo da coletividade a que visa regular e proteger.

\section{CONCLUSÃO}

A copropriedade de bens, ou seja, a propriedade conjunta de um bem por mais de uma pessoa, remonta ao nascimento do próprio direito de propriedade, tanto que o instituto do condomínio pode ser encontrado não apenas em Roma, mas também entre os sumérios, egípcios e na Babilônia, há mais de dois mil anos antes de Cristo.

0 atual modelo de condomínio, adjetivado de edilício, apresenta características próprias, resultando na existência um bem no qual subsistem a propriedade privada de unidades autônomas e a propriedade conjunta de áreas comuns.

Apesar de representar uma realidade fática cada vez mais comum na atualidade, ainda se questiona se o condomínio edilício é uma realidade jurídica e, nesse contexto, se lhe pode ser atribuída a personalidade jurídica. Nesse sentido, a partir de preceitos normais gerais apresentados, por meio de um método dedutivo, o presente trabalho conclui pela possibilidade de os condomínios edilícios terem reconhecida a personalidade jurídica, ou seja, serem titulares de direitos e obrigações.

Respondida afirmativamente essa primeira questão, a dúvida seguinte a ser analisada dizia respeito à possibilidade de, tendo reconhecida a sua personalidade jurídica, poderia ou não o condomínio edilício receber bem em doação.

Nesse tópico, é forçoso reconhecer que, além de prestigiar a sua personalidade jurídica, a resposta afirmativa a essa segunda questão também representa a plena observância dos princípios constitucionais da ordem econômica, em especial os princípios da livre iniciativa, da propriedade privada, da função social da propriedade e do livre exercício da atividade econômica. 
Claro que o reconhecimento de esse direito a ser beneficiário de doação não pode ser absoluto, pois é necessário observar se o bem doado será útil ao condomínio, ou seja, se ele será apto de ser utilizado em benefício dos condôminos e em prol do cumprimento dos fins para os quais o condomínio edilício foi criado.

O problema é que, de forma equivocada, alguns Serviços Registrais têm negado a formalização do ato de doação ao condomínio, suscitando dúvidas nos moldes da Lei de Registros Públicos e remetendo ao Poder Judiciário o enfrentamento do problema, o qual, com fundamento no art. 5ำ da Lei de Introdução às Normas do Direito Brasileiro, que estabelece que o Magistrado, na aplicação da lei, atenderá aos fins sociais aos quais ela se dirige e às exigências do bem comum, vem cumprindo adequadamente o seu papel, determinando o registro das doações, conforme se pode ver das decisões judiciais anteriormente citadas.

0 avanço da doutrina civil em reconhecer, de fato, a personalidade jurídica do condomínio edilício, habilitando-o a receber doação imobiliária e a atual visão dos Tribunais, demonstram a necessidade de superar as concepções antigas existentes sobre o tema, elevando o condomínio edilício ao patamar de sujeito de direito e dever na ordem jurídica.

\section{REFERÊNCIAS}

ARAÚJO, Felipe Fernandes de. Empresários urbanos e produção do espaço residencial: condomínios-clube na Zona Sul de Natal (RN). urbe. Revista Brasileira de Gestão Urbana (Brazilian Journal of Urban Management), v. 7(1), p. 106-121. jan./abr. 2015.

BRASIL. Constituição da República Federativa do Brasil de 1988. Disponível em: $<$ http://www.planalto.gov.br/ccivil_03/Constituicao/Constituicao.htm>. Acesso em: 03/07/2017.

BRASIL. Decreto no 5.481, de 25 de junho de 1928. Dispõe sobre a alienação parcial dos edificios de mais de cinco andares e dá outras providencias. CLBR, 1928. Disponível em: <http:// www.planalto.gov.br/ccivil_03/decreto/1910-1929/D5481.htm>. Acesso em: 03/07/2017.

BRASIL. Decreto-lei no 5.234, de 8 de fevereiro de 1943. Modifica o art. 1o do decreto no 5.481, de 25 de junho de 1928. DOU, de 10/02/1943. Disponível em: <http://www.planalto.gov.br/ccivil_03/Decreto-Lei/1937-1946/Del5234.htm>. Acesso em: 03/07/2017.

BRASIL. Decreto-lei no 4.657, de 4 de setembro de 1942. Lei de Introdução às normas do Direito Brasileiro. DOU, de 09/09/1942. Disponível em: <http://www.planalto.gov.br/ ccivil_03/Decreto-Lei/Del4657compilado.htm>. Acesso em: 03/07/2017.

BRASIL. Lei no 285, de 5 de junho de 1948. Modifica a redação do artigo 1o do Decreto no 5.481, de 25 de junho de 1928, e revoga o Decreto-lei número 5.234, de 8 de fevereiro de 1943. DOU, de 10/06/1948. Disponível em: <http://www.planalto.gov.br/ccivil_03/ leis/1930-1949/L285.htmm>. Acesso em: 03/07/2017. 
BRASIL. Lei no 3.071, de 1ำ de janeiro de 1916. Código Civil dos Estados Unidos do Brasil. DOU, de 05/01/1916. Disponível em: <https://www.planalto.gov.br/ccivil_03/Leis/ L3071.htm>. Acesso em: 03/07/2017.

BRASIL. Lei no 4.591, de 16 de dezembro de 1964. Dispõe sôbre o condomínio em edificações e as incorporações imobiliárias. DOU, de 21/12/1964. Disponível em: <https:// www.planalto.gov.br/ccivil_03/LEIS/L4591.htm>. Acesso em: 03/07/2017.

BRASIL. Lei no 4.864, de 29 de novembro de 1965. Cria Medidas de estímulo à Indústria de Construção Civil. DOU, de 30/12/1965. Disponível em: <http://www.planalto.gov.br/ ccivil_03/LEIS/L4864.htm>. Acesso em: 03/07/2017.

BRASIL. Lei no 6.015, de 31 de dezembro de 1973. Dispõe sobre os registros públicos, e dá outras providências. DOU, de 31/12/1973. Disponível em: <http://www.planalto.gov. br/ccivil_03/Leis/L6015compilada.htm>. Acesso em: 03/07/2017.

BRASIL. Lei no 10.406, de 10 de janeiro de 2002. Institui o Código Civil. DOU, de 01/01/2002. Disponível em: <http://www.planalto.gov.br/ccivil_03/LEIS/2002/ L10406.htm>. Acesso em: 03/07/2017.

BRASIL. Lei no 13.105, de 16 de março de 2015. Código de Processo Civil. DOU, de 17/03/2015. Disponível em: <http://www.planalto.gov.br/ccivil_03/_Ato20152018/2015/Lei/L13105.htm>. Acesso em: 03/07/2017.

BRASIL. Tribunal Regional Federal da 3aㅡ Região. Agravo de Instrumento nํㅜ 79732-SP. Processo no 94.03.079732-0. Relator Desembargador Roberto Haddad. Data de julgamento: 26/05/1998. Publicação DJ 15/09/1998, p. 321.

FIUZA, Cesar. Curso completo de direito civil. Belo Horizonte: Editora Del Rey, 2012.

PEREIRA, Caio Mario da Silva. Instituições de direito civil - direitos reais. 18. ed. Rio de Janeiro: Forense, 2004.

RIO GRANDE DO SUL. Tribunal de Justiça. Décima Sétima Câmara Cível. Apelação Cível no 70069628204 (no CNJ: 0173014-59.2016.8.21.7000). Relator: Desembargador Giovanni Conti. Data do Julgamento: 30/06/2016. Publicação: 12/07/2016.

RIZZARDO, Arnaldo. Condomínio edilício e incorporação imobiliária. 5. ed. ver., atual. e ampl. Rio de Janeiro : Forense, 2017 (ebook).

SANTA CATARINA. Tribunal de Justiça. Câmara Especial Temporária de Direito Civil. Apelação Cível no 2003.001072-6. Relator: Desembargador Luiz César Medeiros. Julgado em $12 / 08 / 2009$.

SANTA CATARINA. Tribunal de Justiça. Primeira Câmara de Direito Civil. Apelação Cível no 2013.014872-6. Relator: Desembargador Sebastião César Evangelista. Julgado em: 07/05/2015.

TARTUCE, Flavio. Manual de direito civil. 2. ed. São Paulo : Editora Método, 2012.

TORRADO, Jesús Lima. Antecedentes normativos de los derechos humanos en la baja edad media. Revista Direito UFMS. Campo Grande, MS - Edição Especial. p. 7-34. jan./jun. 2015

VENOSA, Silvio de Salvo. Direito civil - direitos reais. 3. ed. São Paulo : Editora Atlas, 2013. 